\title{
Effects of acute and chronic level of protein supply on metabolic leucine utilization in growing and mature rats
}

\author{
BY P. J. M. WEIJS, V. V. A. M. SCHREURS, R. E. KOOPMANSCHAP, \\ H. N. A. GROOTEN, A. T. SCHOONMAN AND H. A. BOEKHOLT \\ Department of Human and Animal Physiology, Wageningen Agricultural University, Haarweg 10 , \\ 6709 PJ Wageningen, The Netherlands
}

(Received 5 August 1991-Accepted 7 September 1992)

\begin{abstract}
Effects of acute (meal) and chronic (diet) level of protein supply on metabolic leucine utilization were investigated in growing (10 weeks) and mature ( $>1$ year) rats. Rats were conditioned on a high-protein (HP) diet ( $210 \mathrm{~g}$ casein $/ \mathrm{kg}$ feed) or a low-protein (LP) diet ( $75 \mathrm{~g}$ casein $/ \mathrm{kg}$ feed) from 7 weeks of age. Overnight-fasted rats were offered a HP or LP meal during a $8 \mathrm{~h}{ }^{14} \mathrm{CO}_{2}$ breath test with a constant infusion of either L-[1-14 $\mathrm{C} \mid$ leucine (carboxyl, CL) or $\mathrm{L}-\left[\mathrm{U}-{ }^{14} \mathrm{C} \mid l e u c i n e\right.$ (universal, UL). Before the meal ${ }^{14} \mathrm{CO}_{2}$ output was lower for overnight-fasted rats fed on LP than on $\mathrm{HP}(P<0.001)$, and also lower for growing than for mature rats $(P<0.001)$. Meal ingestion resulted in a rapid increase in ${ }^{14} \mathrm{CO}_{2}$ output. From $2 \mathrm{~h}$ after the start of the meal the effect of acute protein supply on ${ }^{14} \mathrm{CO}_{2}$ output was significant $(P<0.001)$, while the effect of chronic protein supply disappeared for $\mathrm{CL}$. After the meal ${ }^{14} \mathrm{CO}_{2}$ output was transiently lower for growing than for mature rats $(P<0.05)$, especially after the $L P$ meal. The difference in ${ }^{14} \mathrm{CO}_{2}$ output between $\mathrm{CL}$ and $\mathrm{UL}$ increased transiently after the meal, indicating an increase in decarboxylation relative to total oxidation of leucine. In conclusion: (1) metabolic leucine utilization after overnight fasting depends on the level of chronic protein supply and stage of development of the animal, (2) metabolic leucine utilization after feeding depends primarily on the level of acute protein supply, (3) the transient increase in non-protein label retention suggests a temporal oversupply of leucine relative to the actual metabolic state.
\end{abstract}

Leucine metabolism: Metabolic utilization: Protein intake: Meal: Rat

Current estimates of protein and indispensable amino acid (IAA) requirements of adult humans are based on the N-balance technique (FAO/WHO/UNU, 1985). Several authors have stressed the limitations of this technique (Hegsted, 1976; Munro, 1985; Young, 1986). From recent IAA oxidation studies in the fed state at different levels of IAA intake in adult humans, it was concluded that current estimates of IAA requirements were too low (Young et al. 1989). There is no consensus, however, about the metabolic basis for protein and IAA requirements (Millward \& Rivers, 1988; Millward et al. 1991; Young, 1991).

Several studies have investigated the effect of feeding and fasting (Garlick et al. 1980; Motil et al. 1981 ; Clugston \& Garlick, 1982; Rennie et al. 1982; Hoffer et al. 1985; Melville et al. 1989) and the level of chronic protein supply (Millward et al. 1991) on metabolic leucine utilization. These studies, however, involved steady state periods with or without repeated small meals. The effect of normal intermittent feeding on metabolic leucine utilization has not been considered.

In the present study the effects of acute and chronic level of protein supply on metabolic leucine utilization were investigated in growing and mature rats, which have different protein and/or IAA requirements. By means of a ${ }^{14} \mathrm{CO}_{2}$ breath test the meal-induced 
changes in ${ }^{14} \mathrm{CO}_{2}$ output were measured during infusion of $\left[1-{ }^{14} \mathrm{C}\right]-$ and $\left[\mathrm{U}-{ }^{14} \mathrm{C}\right]$ leucine. The difference in ${ }^{14} \mathrm{CO}_{2}$ output between infusion of $\left[1-{ }^{14} \mathrm{C}\right]-$ and $\left[\mathrm{U}-{ }^{14} \mathrm{C}\right]$ leucine has been suggested to be an indication of amino acid oversupply relative to metabolic state of the animal (Schreurs et al. 1992).

\section{MATERIALS AND METHODS \\ Animals and diets}

Growing (9-10 weeks) and mature ( $>1$ year) male Wistar-WU rats (Centre for Small Laboratory Animals, Wageningen Agricultural University, Wageningen, The Netherlands) were housed in individual cages with bedding material (Woody-Clean type 8/15, Broekman Institute Ltd, Someren, The Netherlands). Room temperature was $22-23^{\circ}$, and the light period was from 6.00 hours to 20.00 hours. All rats were provided with a silicon heart catheter through the right jugular vein for constant infusion of tracer, 3 weeks before the experiment (Steffens, 1969). Rats were conditioned on a high-protein (HP) diet (210 g casein $/ \mathrm{kg}$ feed) or a low-protein (LP) diet ( $75 \mathrm{~g}$ casein $/ \mathrm{kg}$ feed) from 7 weeks of age. Composition of diets was reported earlier (Schreurs et al. 1992). From 2 weeks before the experiment feeding was restricted to the period between 9.00 hours and 18.00 hours.

$$
{ }^{14} \mathrm{CO}_{2} \text { breath test }
$$

Overnight-fasted growing rats were subjected to three $8 \mathrm{~h}$ constant infusions of labelled leucine. Tracers, L- $\left[1-{ }^{14} \mathrm{C}\right]$ leucine (carboxyl, CL) and L- $\left[\mathrm{U}-{ }^{14} \mathrm{C}\right]$ leucine (universal, UL) (Amersham, Den Bosch, The Netherlands), were diluted with deionized water and infused at a rate of $250 \mu \mathrm{l} / \mathrm{h}$. Rats were given two infusions with CL $(4.6 \mathrm{kBq} / \mathrm{h} ; 2.0 \mathrm{GBq} / \mathrm{mmol})$ with a $2 \mathrm{~d}$ interval. A further $2 \mathrm{~d}$ later a third infusion was given with $U L(4.6 \mathrm{kBq} / \mathrm{h}$; $11.4 \mathrm{GBq} / \mathrm{mmol})$. At $2 \mathrm{~h}$ after the start of the first infusion rats were offered either a $5 \mathrm{~g} \mathrm{HP}$ or LP meal for $30 \mathrm{~min}$. The same rats were offered the other of the two meals (HP, LP) at the second test. For the third test (UL) only one of two meals was offered.

Mature rats were subjected to two constant infusions of labelled leucine; the same tracers as given to the growing rats were used. First, rats were infused with CL for $8 \mathrm{~h}(4.6 \mathrm{kBq} / \mathrm{h})$, and second, with UL for $7 \mathrm{~h}(21 \cdot 1 \mathrm{kBq} / \mathrm{h})$. At $3 \mathrm{~h}$ after the start of both infusions the rats were offered a HP or LP meal. A small number of mature rats were offered a protein-free meal. CL and UL measurements were not always performed in the same rat.

During the experiment the rat was kept in a perspex cage $(25 \times 25 \times 15 \mathrm{~cm})$, which was ventilated at a rate of $1.51 / \mathrm{min}$. Expired $\mathrm{CO}_{2}$ was trapped in $250 \mathrm{ml} \mathrm{KOH}$ solution $(0.3 \mathrm{~mol} / \mathrm{l})$. Traps were refreshed hourly and $20 \mathrm{ml}$ samples were taken at 15 or $30 \mathrm{~min}$ intervals. A $10 \mathrm{ml}$ sample was mixed with $10 \mathrm{ml}$ liquid scintillation cocktail (Insta-Gel; Packard, Groningen, The Netherlands). Expired radioactivity was determined using a liquid scintillation analyser (TRI-CARB 1900 CA; Packard) and expressed as a percentage of the dose infused during the time interval of the sample (modified for constant infusion from Schreurs et al. 1992).

\section{Statistical analysis}

Group means were analysed with Student's $t$ test (SPSS Inc., 1988). The hourly values in Table 2 were calculated as the average of two or four samples. These values were subjected to analysis of variance (ANOVA); data for protein-free meals were excluded from ANOVA. For growing rats the CL data for the HP and LP meals were obtained from the same rat, therefore the 'meal effect' was nested within the 'diet effect'. The differences between growing and mature rats were then investigated with Student's $t$ test for both the HP meal and the LP meal. 
Table 1. Mean body weights of growing and mature rats

(Mean values with their standard errors)

\begin{tabular}{lllllllll}
\hline \hline Diet ... & \multicolumn{3}{c}{ High protein } & & \multicolumn{3}{c}{ Low protein } \\
\cline { 2 - 5 } & Mean & SE & $n$ & & Mean & SE & $n$ \\
\hline Growing rats & 187 & 12 & 7 & & $138^{*}$ & 5 & 11 \\
Mature rats & 426 & 11 & 14 & & $336^{*}$ & 11 & 16 \\
\hline
\end{tabular}

* Significantly different from high-protein diet, $P<0 \cdot 001$.

\section{RESULTS}

Body weight and feed intake

Table 1 shows the differences in body weight as a result of the level of chronic protein supply for growing and mature rats. Feed intake $(\mathrm{g} / \mathrm{kg}$ body weight per $\mathrm{d}$ ) was not different between diets.

\section{${ }^{14} \mathrm{CO}_{2}$ breath test}

Fig. 1 shows the meal-induced changes in ${ }^{14} \mathrm{CO}_{2}$ output for all groups. In the overnightfasted state (i.e. before the meal) ${ }^{14} \mathrm{CO}_{2}$ output was lower for the LP than for the HP diet $(P<0.001)$ and lower for the growing than for the mature rats $(P<0.001)$. CL and UL results show largely the same differences in the overnight-fasted state (Table 2).

Both CL and UL results in Fig. 1 show the rapid increase in ${ }^{14} \mathrm{CO}_{2}$ output during ingestion of the meal, although the increase is more pronounced for the CL data.

After a protein-free meal ${ }^{14} \mathrm{CO}_{2}$ output decreased to the fasted level, with the same difference between the LP and HP diets $(P<0.05)$. The transient nature of this increase indicated the first response to the meal. This could not be observed in all figures because of the overlap with the second response of ${ }^{14} \mathrm{CO}_{2}$ output to the meal. The second response of ${ }^{14} \mathrm{CO}_{2}$ output to the meal was determined by the protein content of the meal (Table 2 ). After the LP meal ${ }^{14} \mathrm{CO}_{2}$ output was higher compared to the protein-free meal $(P<0 \cdot 05)$, and after the HP meal it was higher compared to the LP meal $(P<0.05)$.

After the meal the effect of diet, as observed in the fasted state, disappeared for the CL results but not for the UL results. The CL results were lower for growing than for mature rats, after the HP meal in hour $2(P<0.05)$ and after the LP meal in hours 2, 3 and 4 $(P<0.005, P<0.05$ and $P<0.1$ respectively). The UL results did not show differences between growing and mature rats.

The bottom row of Fig. 1 shows the difference in ${ }^{14} \mathrm{CO}_{2}$ output between CL and UL curves. This difference increases transiently after ingestion of a meal.

\section{DISCUSSION}

Several studies have investigated the effect of feeding on metabolic leucine utilization in humans (Garlick et al. 1980; Motil et al. 1981; Clugston \& Garlick, 1982; Rennie et al. 1982; Hoffer et al. 1985; Melville et al. 1989). In these studies the specific activity of plasma leucine (or ketoisocaproate) and breath $\mathrm{CO}_{2}$ was measured in the steady state, in order to calculate leucine flux and leucine oxidation. To our knowledge no attempts have been made to investigate non-steady state leucine kinetics, which is more realistic and appreciates physiological limits in the capacity to use dietary protein. In the present study we have developed a model to investigate the non-steady state. At present we accept the limitations 


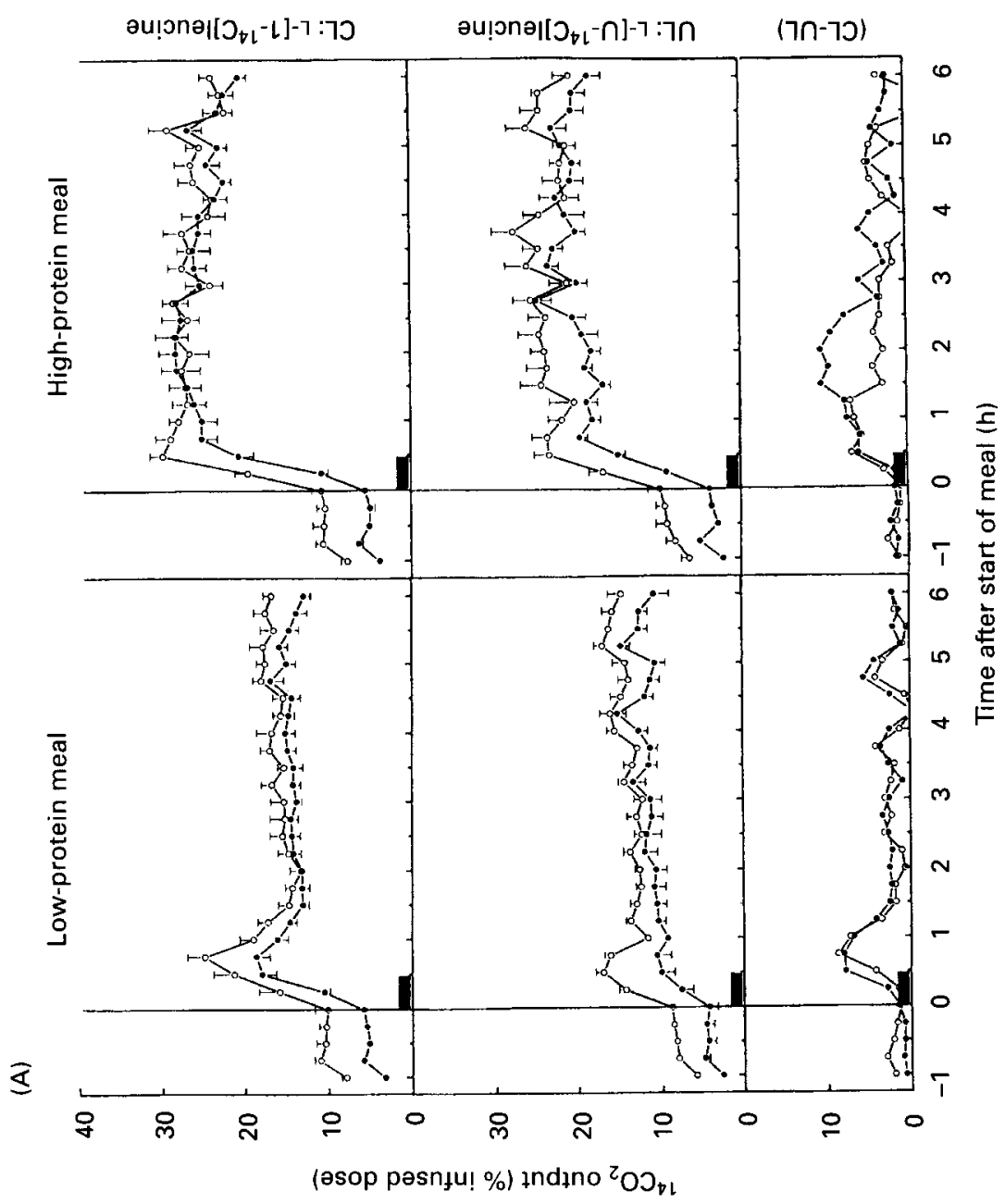




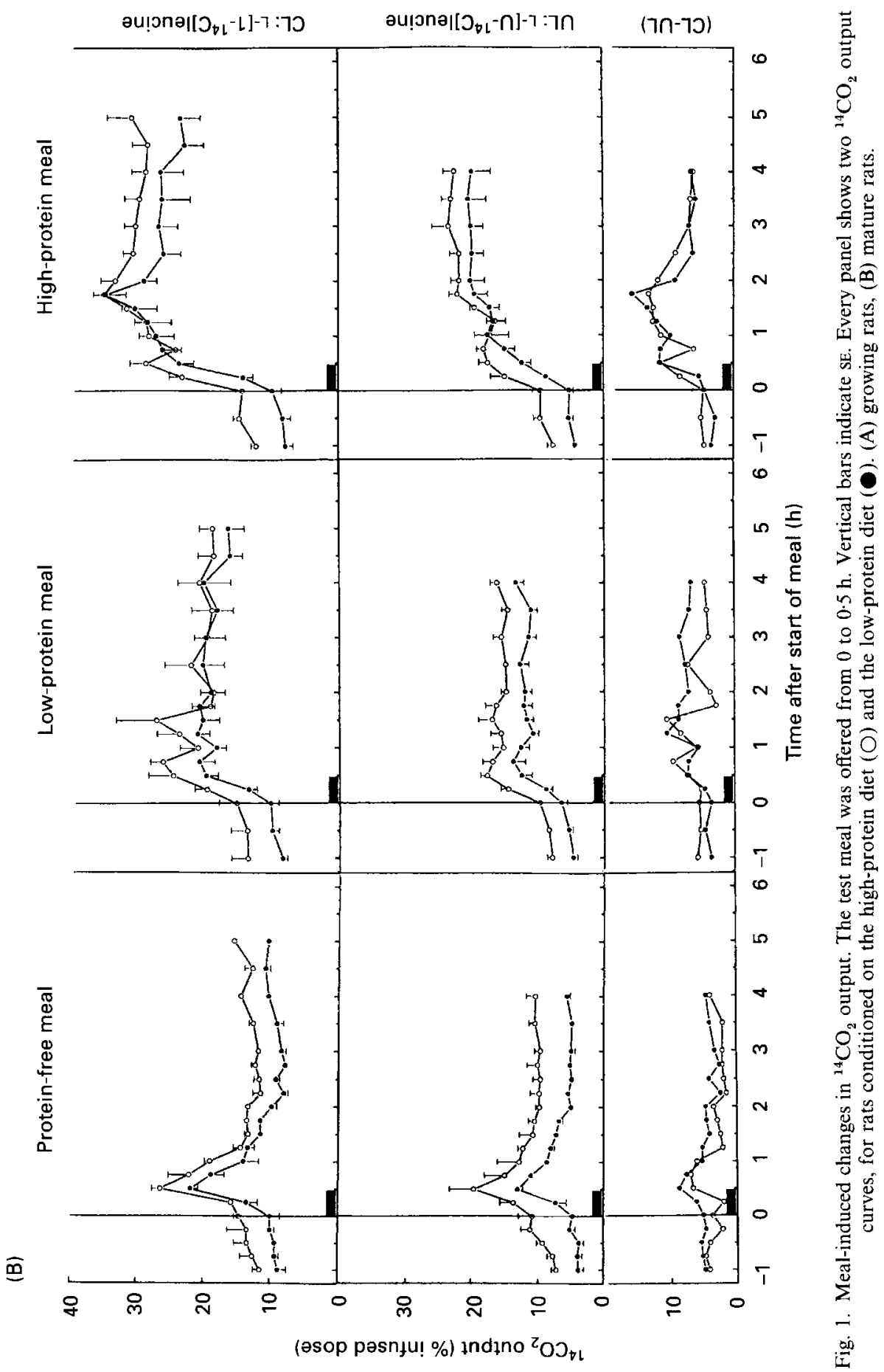


Table 2. Effects of acute (meal) and chronic (diet) $\dagger$ protein supply on ${ }^{14} \mathrm{CO}_{2}$ output $(\%$ infused dose) in growing and mature rats as investigated with constant infusion of different tracers ( $L-\left[1-{ }^{14} \mathrm{C}\right]$ leucine or $L-\left[U-{ }^{14} C\right]$ leucine $) \ddagger$

(Mean values with their standard errors)

\begin{tabular}{|c|c|c|c|c|c|c|c|c|c|c|}
\hline \multirow{3}{*}{$\begin{array}{l}\text { Diet ... } \\
\text { Meal... } \\
\text { Time (h) }\end{array}$} & \multicolumn{4}{|c|}{ High protein } & \multicolumn{4}{|c|}{ Low protein } & & \\
\hline & \multicolumn{2}{|c|}{ High protein } & \multicolumn{2}{|c|}{ Low protein } & \multicolumn{2}{|c|}{ High protein } & \multicolumn{2}{|c|}{ Low protein } & \multicolumn{2}{|c|}{ ANOVA $(P)^{*}$} \\
\hline & Mean & $\mathrm{SE}$ & Mean & $\mathrm{SE}$ & Mean & $\mathrm{SE}$ & Mean & $\mathrm{SE}$ & Diet & Meal \\
\hline \multicolumn{11}{|c|}{$\mathrm{L}-\left[1-{ }^{14} \mathrm{C}\right]$ leucine } \\
\hline \multicolumn{11}{|c|}{ Growing rats } \\
\hline & \multicolumn{2}{|c|}{$(n 7)$} & \multicolumn{2}{|c|}{$(n 7)$} & \multicolumn{2}{|c|}{$(n \perp 1)$} & \multicolumn{2}{|c|}{$(n 11)$} & & \\
\hline 0 & $10 \cdot 5$ & $1 \cdot 0$ & $10 \cdot 5$ & 0.8 & $5 \cdot 4$ & $0 \cdot 4$ & 5.5 & $0 \cdot 2$ & 0.001 & NS \\
\hline 1 & $26 \cdot 1$ & $1-3$ & $20 \cdot 3$ & $1 \cdot 7$ & $20 \cdot 1$ & $1 \cdot 4$ & 15.8 & 0.9 & 0.001 & 0.003 \\
\hline 2 & $26 \cdot 9$ & 1.7 & $15 \cdot 0$ & $1 \cdot 0$ & $27 \cdot 4$ & $1 \cdot 6$ & $13 \cdot 5$ & 0.7 & NS & 0.001 \\
\hline 3 & $26 \cdot 8$ & $1 \cdot 2$ & $15 \cdot 1$ & $1 \cdot 1$ & $27 \cdot 1$ & $1 \cdot 7$ & $14 \cdot 3$ & 0.8 & NS & 0.001 \\
\hline 4 & $26 \cdot 5$ & 1.5 & $16 \cdot 5$ & $1 \cdot 1$ & $25 \cdot 6$ & $1 \cdot 3$ & $14 \cdot 6$ & 1.0 & NS & 0.001 \\
\hline 5 & $25 \cdot 2$ & $1 \cdot 2$ & $16 \cdot 7$ & 0.8 & $23 \cdot 3$ & 0.8 & $15 \cdot 3$ & 1.0 & NS & $0 \cdot 001$ \\
\hline 6 & $24 \cdot 4$ & $1 \cdot 2$ & $17 \cdot 2$ & $1 \cdot 2$ & $22 \cdot 6$ & $1 \cdot 1$ & $14 \cdot 4$ & 0.9 & 0.041 & 0.001 \\
\hline \multicolumn{11}{|c|}{ Mature rats } \\
\hline & \multicolumn{2}{|c|}{$(n 7)$} & \multicolumn{2}{|c|}{$(n 5)$} & \multicolumn{2}{|c|}{$(n 8)$} & \multicolumn{2}{|c|}{$(n 5)$} & & \\
\hline 0 & $14 \cdot 6$ & 0.9 & $14 \cdot 5^{\circ}$ & $2 \cdot 5$ & $9 \cdot 1$ & $1 \cdot 3$ & $10 \cdot 1$ & $1 \cdot 1$ & 0.002 & NS \\
\hline 1 & $26 \cdot 2$ & $1 \cdot 5$ & $23 \cdot 1$ & $2 \cdot 4$ & 22.9 & $2 \cdot 1$ & $18 \cdot 2$ & $1 \cdot 4$ & 0.049 & 0.052 \\
\hline 2 & $32 \cdot 2$ & $1 \cdot 3$ & $22 \cdot 3$ & $3 \cdot 2$ & $30 \cdot 7$ & $2 \cdot 7$ & $20 \cdot 4$ & $2 \cdot 1$ & NS & 0.001 \\
\hline 3 & $30 \cdot 6$ & $1 \cdot 4$ & $21 \cdot 0$ & $2 \cdot 8$ & $26 \cdot 5$ & $2 \cdot 6$ & $20 \cdot 2$ & $3 \cdot 0$ & NS & 0.004 \\
\hline 4 & $29 \cdot 3$ & $1 \cdot 9$ & $20 \cdot 0$ & $3 \cdot 0$ & $26 \cdot 4$ & $3 \cdot 6$ & $19 \cdot 2$ & $3 \cdot 1$ & NS & 0.022 \\
\hline 5 & $29 \cdot 7$ & $2 \cdot 8$ & $19 \cdot 5$ & $2 \cdot 1$ & $23 \cdot 3$ & $2 \cdot 9$ & $16 \cdot 4$ & $2 \cdot 0$ & 0.078 & 0.006 \\
\hline \multicolumn{11}{|c|}{$\mathrm{L}-\left[\mathrm{U}-{ }^{14} \mathrm{C}\right]$ leucine } \\
\hline \multicolumn{11}{|c|}{ Growing rats } \\
\hline & \multicolumn{2}{|c|}{$(n 7)$} & \multicolumn{2}{|c|}{$(n 7)$} & \multicolumn{2}{|c|}{$(n 7)$} & \multicolumn{2}{|c|}{$(n 5)$} & & \\
\hline 0 & $9 \cdot 0$ & $1 \cdot 1$ & 8.4 & $0 \cdot 3$ & $3 \cdot 8$ & $0 \cdot 1$ & $4 \cdot 5$ & 0.7 & 0.001 & NS \\
\hline 1 & $21 \cdot 1$ & 1.6 & $14 \cdot 8$ & $0 \cdot 6$ & $15 \cdot 2$ & 0.5 & $9 \cdot 4$ & $1 \cdot 2$ & 0.001 & 0.001 \\
\hline 2 & $22 \cdot 8$ & $2 \cdot 2$ & $13 \cdot 0$ & 0.5 & $17 \cdot 9$ & 1.0 & $10 \cdot 7$ & $1 \cdot 0$ & 0.014 & 0.001 \\
\hline 3 & $23 \cdot 5$ & $2 \cdot 0$ & $12 \cdot 8$ & 0.7 & $20 \cdot 9$ & 1.5 & $11 \cdot 5$ & $1 \cdot 4$ & NS & 0.001 \\
\hline 4 & $25 \cdot 4$ & 1.9 & $14 \cdot 1$ & 0.6 & $21 \cdot 4$ & $1 \cdot 2$ & $12 \cdot 2$ & 1.0 & 0.030 & 0.001 \\
\hline 5 & $21 \cdot 3$ & $1 \cdot 2$ & $14 \cdot 7$ & $1 \cdot 1$ & $20 \cdot 9$ & $1 \cdot 1$ & $12 \cdot 3$ & 0.8 & NS & 0.001 \\
\hline 6 & $24 \cdot 8$ & $1 \cdot 8$ & $15 \cdot 9$ & 0.6 & $20 \cdot 3$ & 1.0 & $12 \cdot 7$ & 1.0 & 0.005 & 0.001 \\
\hline Mature & rats & & & & & & & & & \\
\hline & & & & & & & & & & \\
\hline 0 & $9 \cdot 8$ & $1 \cdot 0$ & $9 \cdot 2$ & $0 \cdot 5$ & $5 \cdot 4$ & 0.7 & 6.0 & 0.7 & 0.002 & NS \\
\hline 1 & $17 \cdot 1$ & $1 \cdot 2$ & $16 \cdot 2$ & $1 \cdot 1$ & 13.5 & $1 \cdot 5$ & $12 \cdot 1$ & $1 \cdot 3$ & 0.005 & NS \\
\hline 2 & 200 & 0.8 & $16 \cdot 1$ & $1 \cdot 3$ & 18.4 & $1 \cdot 6$ & 11.9 & 0.8 & 0.017 & 0.001 \\
\hline 3 & $22 \cdot 6$ & 1.7 & 15.4 & 0.8 & 19.9 & 1.7 & $12 \cdot 2$ & $1 \cdot 1$ & 0.028 & 0.001 \\
\hline 4 & $22 \cdot 8$ & 10 & 15.6 & 0.9 & $20 \cdot 1$ & $2 \cdot 8$ & $12 \cdot 3$ & 1.0 & 0.033 & 0.001 \\
\hline
\end{tabular}

NS, not significant.

* Analysis of variance for $\mathrm{L}-\left[1{ }^{14} \mathrm{C}\right]$ leucine data of growing rats: 'meal effect' nested within 'diet effect'.

$\dagger$ For details of diets, see p. 118.

$\ddagger$ For details of procedures, see p. 118.

of the model and compare meal-induced changes in metabolic leucine utilization between different physiological conditions.

\section{The model}

During constant infusion of labelled leucine the amount of expired labelled $\mathrm{CO}_{2}$ has been measured. This provides a value for the percentage of labelled leucine that is oxidized. In 
the case of carboxyl-labelled leucine this percentage constitutes the part of labelled leucine that is subjected to decarboxylation, the first irreversible step in the degradation of this amino acid. The percentage decarboxylation indicates which part of the labelled leucine pool is not used for protein synthesis. In this way metabolic amino acid utilization can be studied in a non-steady state, e.g. during the transition from the fasted to the fed state. However, changes in ${ }^{14} \mathrm{CO}_{2}$ output can be the result of (1) changes in the percentage of leucine subjected to decarboxylation or total oxidation, but also of (2) changes in ${ }^{14} \mathrm{CO}_{2}$ recovery and (3) changes in the free leucine pool size and, thus, in the leucine specific activity. The second and third causes might either overestimate or underestimate the real percentage of decarboxylation or total oxidation. Therefore, ${ }^{14} \mathrm{CO}_{2}$ output is not a direct measure of the percentage of leucine subjected to decarboxylation (CL) or total oxidation (UL), but indicates changes in metabolic leucine utilization.

\section{Fasting}

The level of chronic protein supply and stage of development of the animal determine metabolic leucine utilization after an overnight fast. If labelled leucine is not used differently from unlabelled leucine this indicates a higher reutilization of endogenous leucine for the LP diet compared with the HP diet. This is in line with the general idea that adaptation to a LP diet involves a more efficient use of IAA for protein synthesis (Harper, 1986; Young \& Marchini, 1990). It is also in line with a lower amplitude in diurnal cycling of protein (Millward \& Rivers, 1988), since amino acid losses are reduced after an overnight fast. This increase in reutilization of leucine on a LP diet was observed in both growing and mature animals, while growth resulted in an extra increase in reutilization.

\section{Feeding}

The effect of meal ingestion on ${ }^{14} \mathrm{CO}_{2}$ output can be divided into two parts. The first response (up to $1.5 \mathrm{~h}$ ) originates from metabolic changes that are related to meal ingestion and/or carbohydrate feeding. Meal ingestion might result in a general 'stress' response that is not specific for amino acid metabolism. Carbohydrate feeding has been shown to result in a decreased endogenous leucine influx (protein breakdown) (Nissen \& Haymond, 1986; Nair et al. 1987; Pacy et al. 1991), which acutely reduces the free leucine pool size and increases the specific activity. The latter consideration, especially, reduces the validity of the measurement, but it appears from the results that this is only transient.

The second response (after $1.5 \mathrm{~h}$ ) is determined by the protein content of the meal. This indicates that acute dietary amino acid influx into the metabolic pool overrules the effect of endogenous amino acid influx (from protein breakdown) on metabolic leucine utilization. This is in line with the observation that protein breakdown is decreased upon feeding (Garlick et al. 1990). Feeding repeated small meals has been observed to increase the percentage of leucine flux subjected to oxidation in a steady state by about 1.5 times (Garlick et al. 1980; Motil et al. 1981; Clugston \& Garlick, 1982; Rennie et al. 1982; Hoffer et al. 1985; Melville et al. 1989). Intermittent meal ingestion is shown to increase the percentage of labelled leucine as much as six times, depending on the physiologicalnutritional condition before the meal and the protein content of the meal.

In order to emphasize the importance, we have three comments on this observation. First, the overruling effect of acute supply is absent after ingestion of a protein-free meal. The previously-mentioned effect of carbohydrate feeding provides a mechanism to reduce endogenous leucine losses after a protein-free meal, but also a mechanism to gain protein after a LP or HP meal. Secondly, the overruling effect of acute supply is observed both after a LP and a HP meal. Although growth is restricted on a LP diet, a LP meal increases the percentage of labelled leucine that is subjected to decarboxylation. This indicates that even 
a meal with a marginal protein level negatively affects metabolic leucine utilization and thus suggests relative ineffective utilization of the supply of leucine. Thirdly, the percentage of labelled leucine subjected to decarboxylation is lower in the growing animals compared to the mature animals, especially after a LP meal. This indicates that the LP meal particularly can be used more efficiently by growing animals. This might be related to the higher fractional protein synthesis rate in growing than in mature animals (Waterlow et al. 1978). It is well recognized that during adaptation to a different dietary protein level the N-balance shows a delayed response (Munro, 1964). The present study indicates that postprandial amino acid utilization is mainly affected by acute protein supply, with minor influences of the physiological-nutritional condition of the animal to the use of dietary protein. This suggests that the delay in response is due to subsequent postabsorptive amino acid utilization. This is in line with the observation that an acute change to a LP diet reduces protein gain but not subsequent protein loss (Millward et al. 1990).

\section{Potential of breath test}

We suggested earlier (Schreurs et al. 1992) that the combined use of CL and UL in a breath test has potential value in evaluating relative oversupply of an amino acid. During transition from the fasted to the fed state the difference between $\mathrm{CL}$ and UL increases transiently. This increase in ${ }^{14} \mathrm{CO}_{2}$ output is more apparent in CL than in UL measurements, and might be related to the previously mentioned aspects of the first response to a meal. The second response to a meal (between $1.5 \mathrm{~h}$ and $2.5 \mathrm{~h}$ ) shows an increase in the difference between $\mathrm{CL}$ and UL after a HP meal in three cases: growing rats fed on a LP diet, mature rats fed on a LP diet, and mature rats fed on a HP diet. This indicates that in these animals leucine supply with a HP meal is high relative to the ability of the animals to handle it. This is in line with our previous suggestion (Schreurs et al. 1992).

\section{Conclusion}

The present study indicates that (1) metabolic leucine utilization after overnight fasting depends on the level of chronic protein supply and stage of development of the animal, (2) metabolic leucine utilization after feeding depends primarily on the level of acute protein supply, (3) the transient increase in non-protein label retention suggests a temporal oversupply of leucine relative to the actual metabolic state.

Since feeding, especially intermittent feeding, and changes in dietary protein level have a major influence on metabolic leucine utilization, it is likely that dietary protein and IAA requirements change with dietary habits.

\section{REFERENCES}

Clugston, G. A. \& Garlick, P. J. (1982). The response of protein and energy metabolism to food intake in lean and obese man. Human Nutrition Clinical Nutrition 36C, 57-70.

Food and Agriculture Organization/World Health Organization/United Nations University (1985). Energy and Protein Requirements. Report of a joint expert consultation. WHO Technical Report Series no. 724. Geneva: WHO.

Garlick, P. J., Clugston, G. A., Swick, R. W. \& Waterlow, J. C. (1980). Diurnal pattern of protein and energy metabolism in man. American Journal of Clinical Nutrition 33, 1983-1986.

Garlick, P. J., Wernerman, J., McNurlan, M. A. \& Essen, P. (1990). What is the normal response of protein turnover to nutrient supply? Clinical Nutrition 9, 294-296.

Harper, A. E. (1986). Enzymatic basis for adaptive changes in amino acid metabolism. In Proceedings of the XIII International Congress of Nutrition, pp. 409-414 [T. G. Taylor and N. K. Jenkins, editors]. London \& Paris: John Libbey.

Hegsted, D. M. (1976). Balance studies. Journal of Nutrition 106, 307-311.

Hoffer, L. J., Yang, R. D., Matthews, D. E., Bistrian, B. R., Bier, D. M. \& Young, V. R. (1985). Effects of meal consumption on whole body leucine and alanine kinetics in young adult men. British Journal of Nutrition $\mathbf{5 3}$, 31-38. 
Melville, S., McNurlan, M. A., McHardy, K. C., Broom, J., Milne, E., Calder, A. G. \& Garlick, P. J. (1989). The role of degradation in the acute control of protein balance in adult man: failure of feeding to stimulate protein synthesis as assessed by L-[1- $\left.{ }^{13} \mathrm{C}\right]$ Leucine infusion. Metabolism 38, 248-255.

Millward, D. J., Price, G. M., Pacy, P. J. H. \& Halliday, D. (1990). Maintenance protein requirements: the need for conceptual re-evaluation. Proceedings of the Nutrition Society 49, 473-487.

Millward, D. J., Price, G. M., Pacy, P. J. H. \& Halliday, D. (1991). Whole-body protein and amino acid turnover in man: what can we measure with confidence? Proceedings of the Nutrition Society 50, 197-216.

Millward, D. J. \& Rivers, J. (1988). The nutritional role of indispensable amino acids and the metabolic basis for their requirements. European Joumal of Clinical Nutrition 42, 367-393.

Motil, K. J., Matthews, D. E., Bier, D. M., Burke, J. F., Munro, H. N. \& Young, V. R. (1981). Whole-body leucine and lysine metabolism: response to dietary protein intake in young men. American Journal of Physiology 240, E712-E721.

Munro, H. N. (1964). General aspects of the regulation of protein metabolism by diet and hormones. In Mammalian Protein Metabolism, vol. I, pp. 382-481 [H. N. Munro and J. B. Allison, editors]. New York and London: Academic Press.

Munro, H. N. (1985). Historical perspective on protein requirements: objectives for the future. In Nutritional Adaptation in Man, pp. 155-168 [K. Blaxter and J. C. Waterlow, editors]. London and Paris: John Libbey.

Nair, K. S., Halliday, D., Ford, G. C., Heels, S. \& Garrow, J. S. (1987). Failure of carbohydrate to spare leucine oxidation in obese subjects. International Journal of Obesity 11, 537-544.

Nissen, S. \& Haymond, M. W. (1986). Changes in leucine kinetics during meal absorption: effects of dietary leucine availability. American Journal of Physiology 250, E695-E701

Pacy, P. J., Thompson, G. N. \& Halliday, D. (1991). Measurement of whole-body protein turnover in insulindependent (type I) diabetic patients during insulin withdrawal and infusion: comparison of $\left[{ }^{13} \mathrm{C}\right]$ leucine and $\left[{ }^{2} \mathrm{H}_{5}\right]$ phenylalanine methodologies. Clinical Science 80, 345-352.

Rennie, M. J., Edwards, R. H. T., Halliday, D., Matthews, D. E., Wolman, S. L. \& Millward, D. J. (1982) Muscle protein synthesis measured by stable isotope techniques in man: the effects of feeding and fasting. Clinical Science 63, 519-523.

Schreurs, V. V. A. M., Boekholt, H. A., Koopmanschap, R. E. \& Weijs, P. J. M. (1992). The metabolic utilization of amino acids. Potentials of ${ }^{14} \mathrm{CO}_{2}$ breath test measurements. British Journal of Nutrition 67, 207-214.

SPSS Inc. (1988). SPSS/PC ${ }^{+}$Base Manual. Chicago, Illinois: SPSS Inc.

Steffens, A. B. (1969). A method for frequent sampling of blood and continuous infusion of fluids in the rat without disturbing the animal. Physiology and Behavior 4, 833-836.

Waterlow, J. C., Garlick, P. J. \& Millward, D. J. (1978). Protein turnover and growth. In Protein Turnover in Mammalian Tissues and in the Whole Body, pp. 529-594. Amsterdam, New York \& Oxford: North-Holland Publishing Company.

Young, V. R. (1986). Nutritional balance studies: indicators of human requirements or of adaptive mechanisms? Journal of Nutrition 116, 700-703.

Young, V.R. (1991). Nutrient interactions with reference to amino acid and protein metabolism in nonruminants; particular emphasis on protein-energy relations in man. Zeitschrift fur Ernahrungswissenschaft $\mathbf{3 0}$, 239-267.

Young, V. R., Bier, D. M. \& Pellett, P. L. (1989). A theoretical basis for increasing current estimates of the amino acid requirements in adult man, with experimental support. American Journal of Clinical Nutrition 50, 80-92.

Young, V. R. \& Marchini, J. S. (1990). Mechanisms and nutritional significance of metabolic responses to altered intakes of protein and amino acids, with reference to nutritional adaptation in humans. American Journal of Clinical Nutrition 51, $270-289$. 